Australian Journal of
Crop Science

AJCS 14(06):932-939 (2020)

ISSN:1835-2707

doi: 10.21475/ajcs.20.14.06.p2133

\title{
Soil humidity as a productive conditioner of soybean culture through inoculation, co-inoculation and rooting
}

\author{
Evandro Ademir Deak, Thomas Newton Martin*, Glauber Monçon Fipke, Jessica Deolinda Leivas Stecca, \\ Vinícius dos Santos Cunha
}

Department of Crop science, Universidade Federal de Santa Maria, Santa Maria, RS, Brazil

*Corresponding author: martin.ufsm@gmail.com

Abstract

In the soybean crop, the practice of inoculation is crucial for producing high yields. This is because biological nitrogen fixation (BNF) is the main supplier of the nutrient demand for this crop. However, a few environmental variables can also greatly influence the survival of the bacteria that control this process. In this context, the present work was performed to confirm the many ways in which soil moisture affects this process. In the field, we conducted two experiments at the times of the two sowing dates, $11 / 24 / 2015$ and 12/17/2015, adopting the factorial $7 \times 2$ design, with four replications. The inoculation treatments included, non-inoculated (NI); not inoculated along with the nitrogen supplied at the $200 \mathrm{~kg} \mathrm{ha}^{-1}(\mathrm{NI}+\mathrm{N})$ dosage; inoculation with Bradyrhizobium [I (Brady)]; root enhancers (R); inoculation with Bradyrhizobium + root enhancers (I+R); co-inoculation with Bradyrhizobium + Azospirillum brasilense (I+Azo); co-inoculation with Bradyrhizobium + Azospirillum brasilense + root enhancers $(I+A z O+R)$. The second factor included was the use or absence of a water jet ( $\left.200 \mathrm{~L} \mathrm{ha}{ }^{-1}\right)$ directed onto the seeds in the sowing furrow. Then estimations of the initial establishment of the plants, nodulation, and productivity components were measured. Water supplied to the sowing furrow had no effect on soybean nodulation and yield components. Co-inoculation promoted nodulation in soybean plants, particularly in dry mass of the nodules and number of nodules per plant.

Keywords: Bradyrhizobium spp.; Azospirillum brasilense; phytohormones; nutrients; nitrogen.

Abbreviations: A. brasilense_Azospirillum brasilense; N_nitrogênio; $\mathrm{N}_{2}$ atmospheric nitrogen; BNF_biological nitrogen fixation; NFB_nitrogen fixing bacteria; PGPB_plant growth promoting bacteria; NNP_Number of nodules per plant; MNP_mass of nodules per plant; DMP_dry mass of aerial plant parts in R2; FP_final population of the plants; IFP_insertion of the first pod; PH_plant height; NPP_number of pods per plant; NGP_number of grains per pod; MTG_thousand grain mass; GY_grain yield.

Introduction

The soybean grain [Glycine max (L.) Merrill] is the primary product of Brazil because of its significance as food, for both human beings and animals (Conab, 2017), as well as for its rich content of oil and protein (40\%) (Paiola et al., 2008). Brazil ranks second in the world in soybean production, essentially because of the conducive environmental milieu present and the technologies applied. This ensures that soybean is economically crucial in the economy of the country (Hungria et al., 2005). Its constituents comprise about $90 \%$ of nitrogen $(\mathrm{N})$ in its organic form, like amino acids, proteins, amines, purines, coenzymes, besides others (Sfredo and Borkert, 2004).

In order to produce one ton of soybean, around $78 \mathrm{~kg}$ of $\mathrm{N}$ is needed (Prado, 2008). The chief sources of available $\mathrm{N}$ include decomposed organic matter, nitrogen fertilizers, and biological nitrogen fixation (BNF) (Domingos et al., 2015). The BNF process in soybean occurs through the symbiosis between the bacteria of the genus Bradyrhizobium spp., and the soybean plants (Campos et al., 2001). In this sense, utilizing the microorganisms that can fix the atmospheric nitrogen in the soil is a highly significant technology, which can ensure that the Brazilian soybeans are even more valuable and competitive in the global market.

It is common knowledge, for over several decades, that symbiosis exists between the soybean plants and Bradyrhizobium bacteria; however, the inoculation process and environmental conditions are not always sufficiently conducive which prevents the BNF process from maximum potential expression (Sediyama, 2009). The chief characteristic of the Bradyrhizobium is to form nodules in the plant roots wherever the soy plants are housed and perform the BNF reactions. Nitrogenase is the enzyme which executes this process, in which the atmospheric $\mathrm{N}_{2}$ is fixed as ammonia $\left(\mathrm{NH}_{3}\right)$. The ammonia is rapidly converted into ammonium $\left(\mathrm{NH}_{4}^{+}\right)$, amides and ureides. These are then transported to the aerial plant parts where they will enter the $\mathrm{N}$ metabolism process (Ormeño-Orrillo et al., 2013). In this sense, inoculation using nitrogen fixing bacteria (NFB) is the lowest cost-effective option for soybean cultivation, as against merely applying nitrogen fertilizers (Hungria et al., 2013). Thus, new studies are continuously being elaborated to raise the environmental conditions required for the bacteria, as well as to identify the species and bacterial 
associations that may generate the synergistic effects on the BNF (Barbáro et al., 2009; Hungria et al., 2015).

Against this setting, co-inoculation appears to be an approach in the soybean cultivation with the bacteria of the genus Bradyrhizobium in association with the bacteria of the species Azospirillum brasilense. Azospirillum brasilense is part of the plant growth promoting group of bacteria (PGPB). They earned this named for their capacity to colonize the plant roots and stimulate root growth (Kloepper et al., 1989). Azospirillum brasilense inoculated plants exhibited a higher root mass, by encouraging nutrient absorption and ascribing this response to the generation of the growth hormones, particularly the auxins, gibberellins and cytokinins (Tien et al., 1979). This technique of co-inoculation has produced good results in the soybean and bean cultivation, inducing increased shoot and root growth, and boosting the grain harvest (Benintende et al., 2010).

The BNF efficiency is environment dependent and based on the region in which the bacteria are introduced, interrupting their multiplication and mobility. The other factors which also interfere include soil acidity, water stress and increased temperatures (Hungria et al., 2000). While the BNF is influenced by these factors, among others, high soil temperatures and low humidity are the prime reasons for the low nodulation and thus the decreased quantity of the Nitrogen fixed (Hungria et al., 2000, 2015). As soybean seed germination is affected by water availability (Marcos Filho, 1986), this will in turn interfere with the root emission and the signal exchange process between the plants and bacteria.

One of the popular technologies generally employed in soybean cultivation is the use of fungicides and insecticides to treat the seeds. Also, in several instances, plant growth regulators are introduced, which induce growth and developmental changes in the plants (Henning, 2005). Other reports cite the addition of products termed biostimulants and bioregulators, which are able to change the physiological processes in the plants (Castro and Vieira, 2001). One more popular technology employed is to supplement the seeds with nutrients. Today, the availability of several formulated products containing macronutrients and micronutrients enables mineral supplementation to be given through the seeds. By adding these elements to the seeds, the contact between the seedlings and nutrients is facilitated, and the initial development is speeded up, in addition to establishing the root system (Sfredo, 2010). Cobalt and molybdenum are the main among the several nutrients utilized most in the soybean cultivation, because of the part they play in the BNF process (Taiz and Zieger, 2013).

The objective of this work was to verify the manner in which soil moisture conditioning affects the inoculation, co-inoculation in a rooting plant.

\section{Results and discussions}

From the extract of the water balance data it was obvious that there was no water restriction in the initial stage of the culture establishment (Fig 1). However, in January, precipitation decreased, although yields of $4000 \mathrm{~kg} \mathrm{ha}^{-1}$ on average were achieved.
According to the soil temperature records noted down at 9 and 15 o'clock every day, no temperature value exceeded 35 oC up to $5 \mathrm{~cm}$ depth (Fig 2). For this evaluation period it was likely that the temperature exerted no effect on the survival of the Bradyrhizobium bacteria in the soil. Hungria et al. (1997) purported that 27 to $40{ }^{\circ} \mathrm{C}$ was the ideal temperature for BNF in the legumes if the temperature crossed $37^{\circ} \mathrm{C}$ it could not only impact the survival of the rhizobia, it could also induce genetic alterations, and thus produce less efficient individuals in the BNF process.

Soybean yield corresponds to the productivity components, the number of plants per area, number of vegetables per plant, number of grains per legume and mass of the grains, apart from the environment, which directly impact these components. In both the experiments, the treatments did not inhibit either the germination or crop establishment. The final plant population too was unaffected by the treatments (Table 1). Soybean reveals plasticity with regard to the number of plants, adjusting the number of branches, number of pods and grains per plant, depending upon the growth type, as well as the genetic and environmental factors (Aguila et al., 2011). While for experiment 1, the number of pods and grain mass were significant, for experiment 2 the grain mass alone showed a significant difference. According to Brandalero et al., (2009) the productivity changes could also be related to the changes in the nodulation components, like nodule number and mass. Perini et al. (2012) in their correlation analysis of the components of yield with grain yield, noted that for cultivars having a specific cycle the components with the greatest correlation with productivity were the number of pods per plant and grain mass.

In the context of NNP, experiments 1 and 2 showed the mean nodulation to be 125 and 68 nodules, respectively per plant (Table 2). While the seed inoculation was efficient, the treatments with co-inoculation were superior. Experiment 1 registered an increase of 73 and $34 \%$ in the NNP compared to the uninoculated control and inoculation with Bradyrhizobium, respectively. For MNP, the treatments having the co-inoculation showed superiority to the other treatments. Nodulation in the plants was highly significant for the BNF, as it indicates the presence of the bacteria controlling this process. Hungria et al. (2007) stated that for the soybean crop, the presence of 15 to 30 nodules per plant in the field during the flowering stage was indicative of good nodulation, or in the instance of MNP, between 100 and $200 \mathrm{mg}$ of dry nodules per plant. In the co-inoculation treatments, the highest NNP (Table 2 ) is most likely related to the heightened generation of the growth hormones like auxins, cytokinins and gibberellins, as well as phosphate solubilization and production of siderophores (Hungria et al., 2013). The root system in these plants revealed morphological changes with an increase in root number and density, besides the earlier emission (Tien et al., 1979). The presence of more numbers of roots and root hairs leads to more of the soil volume getting occupied which, due to the low bacterial mobility, enhances the contact between the bacteria and roots, and thus encourages nodule formation with more efficient bacteria. 
Table 1. Initial population of plants in V2 (x 1000) (IP, plants ha ${ }^{-1}$ ), and final population of plants in R8 (x 1000) (FP, plants ha $\left.{ }^{-1}\right)$, based on the inoculations in soybean. Crop season of 2015/2016, in Santa Maria, RS.

\begin{tabular}{lcccc}
\hline & \multicolumn{2}{c}{ Experiment 1 } & \multicolumn{2}{c}{ Experiment 2 } \\
\hline TRAT $^{*}$ & $\mathrm{IP}$ & $\mathrm{FP}$ & $\mathrm{IP}$ & $\mathrm{FP}$ \\
\hline $\mathrm{NI}$ & $280.0^{\mathrm{ns}}$ & $265.4^{\mathrm{ns}}$ & $310.1^{\mathrm{ns}}$ & $309.8^{\mathrm{ns}}$ \\
$\mathrm{NI}+\mathrm{N}$ & 266.6 & 236.5 & 304.0 & 296.2 \\
$\mathrm{I}$ (Brady) & 251.2 & 249.0 & 321.6 & 324.0 \\
$\mathrm{R}$ & 264.1 & 243.8 & 317.5 & 315.2 \\
$\mathrm{I+R}$ & 255.0 & 227.3 & 308.3 & 308.0 \\
$\mathrm{I}+$ AZO & 265.7 & 245.8 & 319.7 & 304.6 \\
I+AZO+R & 249.9 & 220.3 & 330.8 & 315.7 \\
\hline CV \% & 8.8 & 10.6 & 5.3 & 6.0 \\
Average & 261.8 & 241.2 & 316.0 & 310.0 \\
\hline
\end{tabular}

*Treatments: $\mathrm{NI}$ - not inoculated; $\mathrm{NI}+\mathrm{N}$ - not inoculated with $200 \mathrm{~kg} \mathrm{~N} \mathrm{ha}{ }^{-1} ; \mathrm{I}($ Brady) - Bradyrhizobium inoculation; R - root enhancers; I+R - Bradyrhizobium + root enhancers; I+AZO - co-inoculation with Bradyrhizobium + Azospirillum brasilense; I+AZO+R - co-inoculation of Bradyrhizobium + Azospirillum brasilense + root enhancers.

${ }^{\mathrm{n}}$ not significant by the $\mathrm{F}$ test.

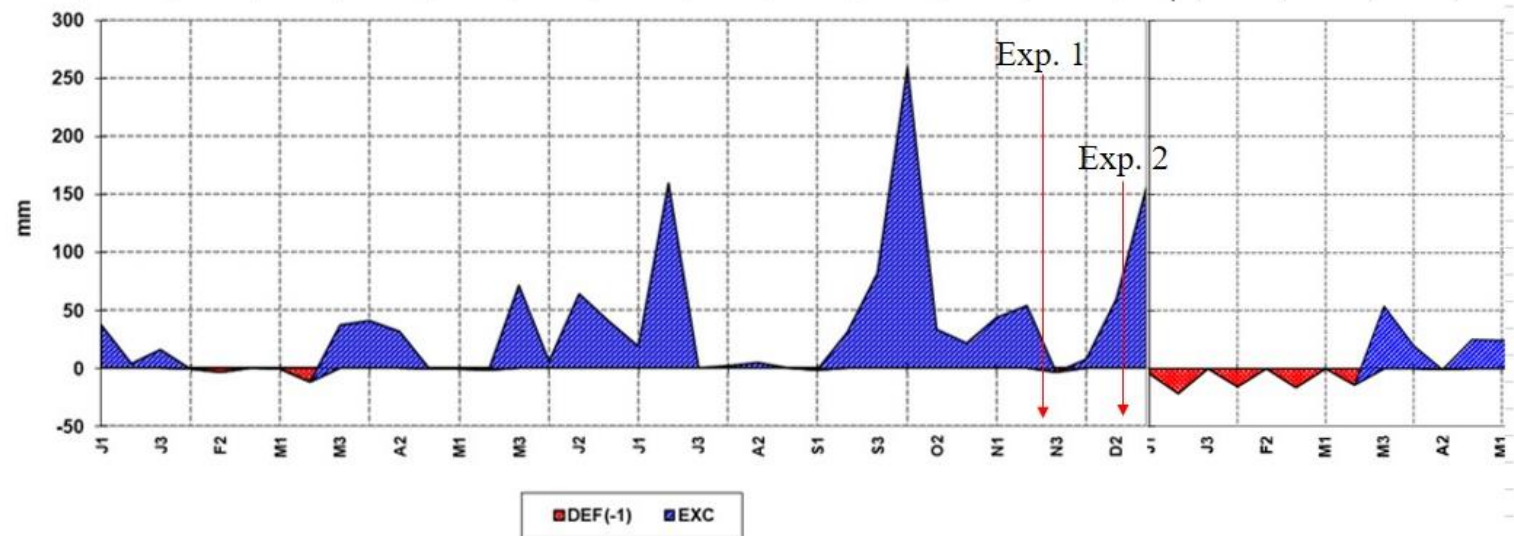

Fig 1. Water balance from January 2015 to May 2016, with the sowing dates for the two experiments, Santa Maria, RS, 2016.

Table 2. Number of nodules per plant in R2 (NNP, $n$ o plant ${ }^{-1}$ ), dry mass of nodules in R2 (MNP, mg plant ${ }^{-1}$ ), dry mass of aerial plant parts in R2 (DMP, g plant ${ }^{-1}$ ), in response to different inoculations in soybean. Crop season of 2015/2016, in Santa Maria, RS.

\begin{tabular}{lcccccc}
\hline & \multicolumn{3}{c}{ Experiment 1 } & \multicolumn{3}{c}{ Experiment 2 } \\
\hline TRAT $^{*}$ & NNP & MNP & DMP & NNP & MNP & DMP \\
\hline $\mathrm{NI}$ & $99.9 \mathrm{c}^{* *}$ & $486.3 \mathrm{~b}$ & $15.7^{\text {ns }}$ & $70.1 \mathrm{~b}$ & $207.9 \mathrm{a}$ & $14.3^{\text {ns }}$ \\
$\mathrm{NI}+\mathrm{N}$ & $84.5 \mathrm{c}$ & $171.9 \mathrm{c}$ & 17.5 & $28.1 \mathrm{c}$ & $40.5 \mathrm{~b}$ & 15.1 \\
$\mathrm{I}$ (Brady) & $128.3 \mathrm{~b}$ & $496.0 \mathrm{~b}$ & 14.4 & $91.5 \mathrm{a}$ & $229.9 \mathrm{a}$ & 13.4 \\
$\mathrm{R}$ & $122.7 \mathrm{~b}$ & $513.5 \mathrm{~b}$ & 17.5 & $80.4 \mathrm{a}$ & $223.8 \mathrm{a}$ & 15.2 \\
$\mathrm{I+R}$ & $113.2 \mathrm{~b}$ & $510.1 \mathrm{~b}$ & 15.2 & $74.9 \mathrm{~b}$ & $200.9 \mathrm{a}$ & 14.7 \\
I+AZO & $172.4 \mathrm{a}$ & $574.3 \mathrm{a}$ & 16.0 & $64.3 \mathrm{~b}$ & $191.6 \mathrm{a}$ & 14.8 \\
I+AZO+R & $159.8 \mathrm{a}$ & $551.1 \mathrm{a}$ & 14.4 & $71.9 \mathrm{~b}$ & $195.7 \mathrm{a}$ & 15.1 \\
\hline CV \% & 12.8 & 11.3 & 21.9 & 18.0 & 24.4 & 14.7 \\
Average & 125.8 & 471.9 & 15.8 & 68.7 & 184.3 & 14.7 \\
\hline
\end{tabular}

*Treatments: $\mathrm{Nl}$ - not inoculated; $\mathrm{Nl}+\mathrm{N}$ - not inoculated with $200 \mathrm{~kg} \mathrm{~N} \mathrm{ha}^{-1}$; I(Brady) - Bradyrhizobium inoculation; $\mathrm{R}$ - root enhancers; I+R - Bradyrhizobium + root enhancers; I+AZO - co-inoculation with Bradyrhizobium + Azospirillum brasilense; I+AZO+R - co-inoculation of Bradyrhizobium + Azospirillum brasilense + root enhancers. ** averages followed by the same letter in the column do not differ from each other by the Skott-Knott test $(\alpha \leq 0.05)$. ${ }^{\text {ns }}$ not significant by the $\mathrm{F}$ test. 

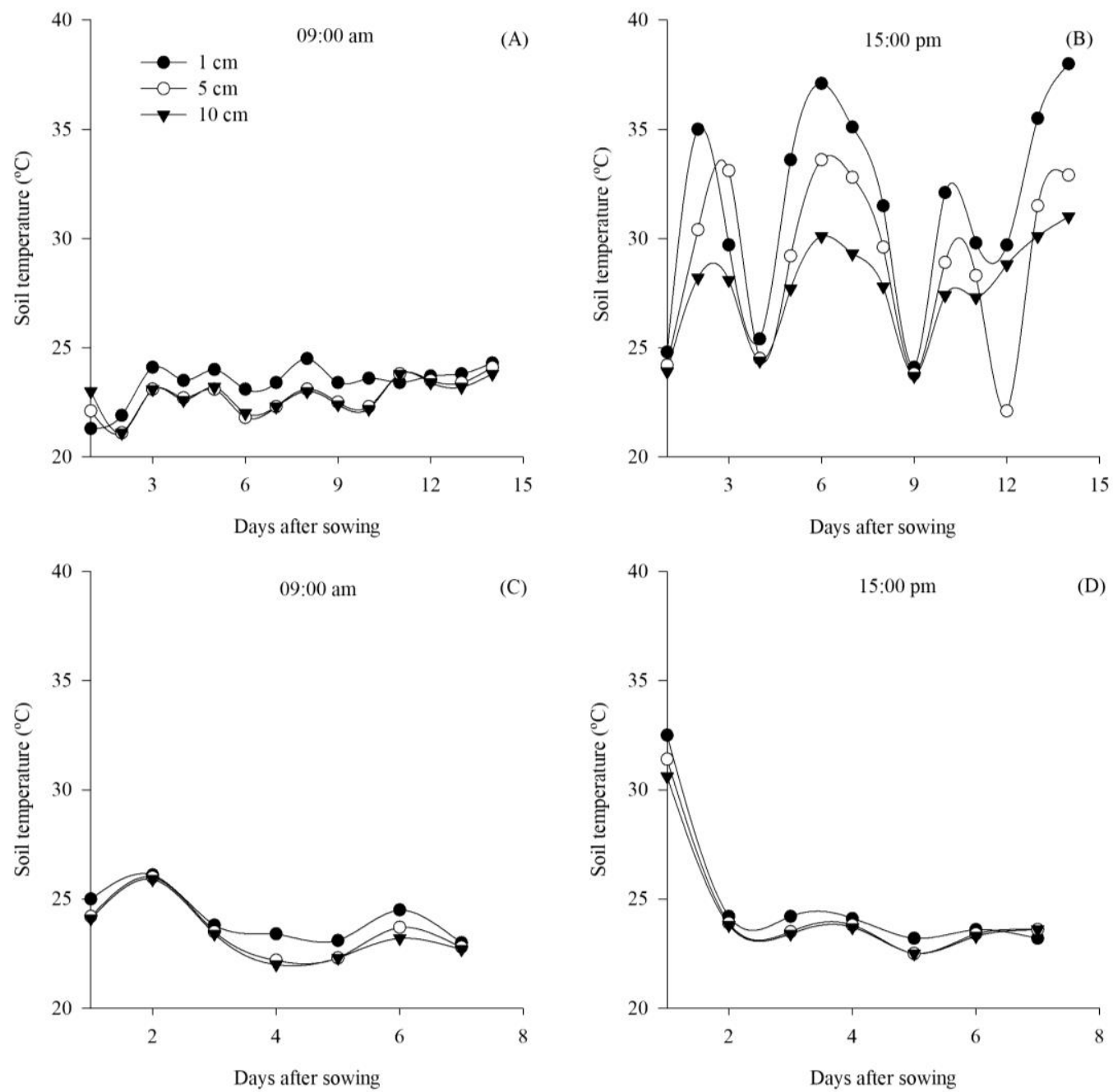

Fig 2. Soil temperature post sowing (1,5 and $10 \mathrm{~cm}$ depth). Experiment 1 (A and B), experiment 2 (C and D). Crop season of 2015/2016, in Santa Maria, RS.

Table 3. Insertion of the first pod (IFP, $\mathrm{cm}$ ) and plant heights $(\mathrm{PH}, \mathrm{cm})$, based on the different inoculations in soybean. Crop season of 2015/2016, in Santa Maria, RS.

\begin{tabular}{|c|c|c|c|c|}
\hline \multirow[b]{2}{*}{ TRAT $^{*}$} & \multicolumn{2}{|c|}{ Experiment 1} & \multicolumn{2}{|c|}{ Experiment 2} \\
\hline & IFP & $\mathrm{PH}$ & IFP & $\mathrm{PH}$ \\
\hline $\mathrm{NI}$ & $24,9 b^{* *}$ & $90.1 \mathrm{~b}$ & $21.2^{\mathrm{ns}}$ & $94.5^{\text {ns }}$ \\
\hline $\mathrm{NI}+\mathrm{N}$ & $32.0 \mathrm{a}$ & $101.8 \mathrm{a}$ & 22.7 & 94.7 \\
\hline I (Brady) & $23.1 \mathrm{~b}$ & 89.2 b & 21.2 & 96.4 \\
\hline $\mathrm{R}$ & $22.4 \mathrm{~b}$ & $84.7 \mathrm{~b}$ & 19.5 & 93.8 \\
\hline I+R & $24.8 \mathrm{~b}$ & $90.7 b$ & 22.6 & 96.5 \\
\hline I+AZO & $25.4 \mathrm{~b}$ & $91.8 \mathrm{~b}$ & 20.0 & 92.7 \\
\hline $\mathrm{I}+\mathrm{AZO}+\mathrm{R}$ & $24.4 \mathrm{~b}$ & $89.8 \mathrm{~b}$ & 20.2 & 96.3 \\
\hline CV \% & 13.8 & 6.2 & 13.0 & 5.1 \\
\hline Average & 25.3 & 91.1 & 21.1 & 95.0 \\
\hline
\end{tabular}

*Treatments: NI - not inoculated; NI+N - not inoculated with $200 \mathrm{~kg} \mathrm{~N}^{-1}{ }^{-1}$ I(Brady) - Bradyrhizobium inoculation; R - root enhancers; I+R - Bradyrhizobium + root enhancers; I+AZO - co-inoculation with Bradyrhizobium + Azospirillum brasilense; I+AZO+R - co-inoculation of Bradyrhizobium + Azospirillum brasilense + root enhancers. ** averages followed by the same letter in the column do not differ from each other by the Skott-Knott test $(\alpha \leq 0.05)$. ${ }^{\text {ns }}$ not significant by the $\mathrm{F}$ test. 
Table 4. Number of pods per plant (NNP, $n \circ$ plant ${ }^{-1}$ ), number of grains per pod (NGP, $n=$ pod $-{ }^{1}$ ), thousand grain mass (MTG, g) and grain yield $\left(\mathrm{GY}, \mathrm{kg} \mathrm{ha}^{-1}\right)$, for the different inoculations, with and without the addition of water in the sowing groove. Crop season of 2015/2016, Santa Maria, RS.

\begin{tabular}{|c|c|c|c|c|c|c|}
\hline \multicolumn{7}{|c|}{ Experiment 1} \\
\hline \multirow{2}{*}{ TRAT $^{*}$} & \multirow{2}{*}{ NPP } & \multirow{2}{*}{ NGP } & \multirow{2}{*}{ MTG } & \multicolumn{3}{|c|}{ GY } \\
\hline & & & & WITH & & WITHOUT \\
\hline $\mathrm{NI}$ & $73.4 b^{* *}$ & $2.2^{\mathrm{ns}}$ & $138.7 \mathrm{~b}$ & $4504 \mathrm{bA}$ & & $4313 \mathrm{aA}$ \\
\hline $\mathrm{NI}+\mathrm{N}$ & $72.5 \mathrm{~b}$ & 2.2 & $137.8 b$ & $4252 \mathrm{bA}$ & & $4121 \mathrm{aA}$ \\
\hline I (Brady) & $73.9 \mathrm{~b}$ & 2.2 & $141.9 \mathrm{a}$ & $5024 \mathrm{aA}$ & & $3930 \mathrm{bB}$ \\
\hline $\mathrm{R}$ & $103.9 \mathrm{a}$ & 2.2 & $142.4 \mathrm{a}$ & $4884 \mathrm{aA}$ & & $4199 \mathrm{aB}$ \\
\hline$I+R$ & 80.7 b & 2.2 & $135.3 \mathrm{c}$ & 4417 bA & & $4242 \mathrm{aA}$ \\
\hline I+AZO & $79.6 \mathrm{~b}$ & 2.2 & $134.4 \mathrm{c}$ & $4342 \mathrm{bA}$ & & 3942 bB \\
\hline $\mathrm{I}+\mathrm{AZO}+\mathrm{R}$ & $77.2 \mathrm{~b}$ & 2.2 & $134.8 \mathrm{c}$ & $4270 \mathrm{bA}$ & & $4132 \mathrm{aA}$ \\
\hline CV \% & 23.0 & 3.9 & 2.0 & & 3.3 & \\
\hline Average & 80.2 & 2.2 & 137.9 & & 4326 & \\
\hline \multicolumn{7}{|c|}{ Experiment 2} \\
\hline $\mathrm{NI}$ & $61.6^{\mathrm{ns}}$ & $2.4^{\mathrm{ns}}$ & $130.4 \mathrm{a}$ & \multicolumn{3}{|c|}{$3809 \mathrm{c}$} \\
\hline $\mathrm{NI}+\mathrm{N}$ & 63.4 & 2.4 & $122.4 \mathrm{c}$ & \multicolumn{3}{|c|}{$3679 d$} \\
\hline I (Brady) & 59.4 & 2.4 & $131.8 \mathrm{a}$ & \multicolumn{3}{|c|}{3966 b } \\
\hline $\mathrm{R}$ & 58.2 & 2.4 & $133.5 \mathrm{a}$ & \multicolumn{3}{|c|}{$4141 \mathrm{a}$} \\
\hline$I+R$ & 58.5 & 2.4 & $126.8 b$ & \multicolumn{3}{|c|}{3805 c } \\
\hline I+AZO & 55.1 & 2.4 & $124.8 b$ & \multicolumn{3}{|c|}{$3749 c$} \\
\hline $\mathrm{I}+\mathrm{AZO}+\mathrm{R}$ & 60.5 & 2.4 & $126.7 \mathrm{~b}$ & \multicolumn{3}{|c|}{$3667 d$} \\
\hline CV \% & 18.5 & 3.0 & 2.3 & \multicolumn{3}{|c|}{2.4} \\
\hline Average & 59.6 & 2.4 & 128.0 & \multicolumn{3}{|c|}{3831} \\
\hline
\end{tabular}

Table 5. The effect of water in the sowing furrow on the initial plant population in V2 (x 1000) (IP, plants ha $\left.{ }^{-1}\right)$, number of nodules in R2 (NNP, no plant ${ }^{-1}$ ), nodule dry mass in R2 (MNP, plant ${ }^{-1}$ ), dry mass of aerial plant parts in R2 (DMP, g plant ${ }^{-1}$ ), final population of the plants $\left(x\right.$ 1000) (FP, plants ha ${ }^{-1}$ ), insertion of the first pod (IFP, cm), plant height $(\mathrm{PH}, \mathrm{cm})$, number of pods per plant (NNP, no plant $^{-1}$ ), number of grains per pod (NGP, no pod ${ }^{-1}$ ), thousand grain mass, (MTG, g) and grain yield (GY, $\mathrm{kg} \mathrm{ha}^{-1}$ ). Experiments were performed in Santa Maria, RS, Crop season of 2015/2016.

\begin{tabular}{|c|c|c|c|c|c|c|c|c|c|c|c|}
\hline \multicolumn{12}{|c|}{ Experiment 1} \\
\hline TRAT* & IP & NNP & MNP & DMP & FP & IFP & $\mathrm{PH}$ & NPP & NGP & MTG & GY \\
\hline WITH & $252.2^{\mathrm{ns}}$ & $124.4^{\mathrm{ns}}$ & $472.1^{\mathrm{ns}}$ & $16.2^{\mathrm{ns}}$ & $241.8^{\text {ns }}$ & $25.5^{\mathrm{ns}}$ & $90.4^{\mathrm{ns}}$ & $77.8^{\mathrm{ns}}$ & $2.2^{\mathrm{ns}}$ & $137.8^{\text {ns }}$ & $4527^{* *}$ \\
\hline WITHOUT & 271.4 & 127.2 & 471.0 & 15.4 & 240.5 & 25.1 & 91.9 & 82.5 & 2.2 & 138.1 & 4126 \\
\hline \multicolumn{12}{|c|}{ Experiment 2} \\
\hline WITH & $316.8^{\text {ns }}$ & $67.1^{\text {ns }}$ & $171.2^{\text {ns }}$ & $15.1^{\mathrm{ns}}$ & $309.6^{\text {ns }}$ & $21.1^{\mathrm{ns}}$ & $95.0^{\text {ns }}$ & $59.3^{\text {ns }}$ & $2.4^{\mathrm{ns}}$ & $127.7^{\text {ns }}$ & $3867^{* *}$ \\
\hline WITHOUT & 315.2 & 70.4 & 197.4 & 14.2 & 311.4 & 21.0 & 94.9 & 59.9 & 2.4 & 128.4 & 3794 \\
\hline
\end{tabular}

* Treatments: WITH: with water in the sowing furrow at the time of sowing; WITHOUT: without any water in the sowing groove. ${ }^{* *}$ treatments differ from each other by the non-significant. ${ }^{\text {ns }}$ not significant.

For DMP, no significant difference was recorded for the two experiments (Table 2); this was probably because that the amount of bacteria present in the soil was enough to supply adequate $\mathrm{N}$ for the crop during the entire cycle. However, in the present study, neither the quantification assessments of the bacteria present in the soil nor occupation of the bacteria in the nodules was done. Benintende et al. (2010) confirmed a higher accumulation of the DMP biomass in the soybean crop with co-inoculation when compared to the inoculation with Bradyrhizobium alone. However, the highest accumulation of DMP and $\mathrm{N}$ for the co-inoculation treatments were verified from the R2 stage, but in the present experiment, this evaluation was performed only in the R2 stage.

Fertilization performed with the addition of mineral N (200 $\mathrm{kg} \mathrm{ha}^{-1}$ ) was found to partially inhibit the nodule formation in the two experiments (Table 2). It may be that the nodule formation process is either reversible or not, based on the $\mathrm{N}$ availability (Hungria et al., 2007). Also, this treatment registered the lowest grain yield at both sowing times, not justifying its use (Table 4).

With respect to the IFP and PH, experiment 1 alone revealed a significant effect (Table 3). Therefore, the treatment showing the highest average was the one which received the fertilization with mineral $N$. This was because of the availability of the $\mathrm{N}$ when it was added in the mineral form during the early developmental stages of the crop; the BNF-dependent treatments need the energy expenditure of the plant, which becomes non-essential when the nutrient is provided in readily available forms (Hungria et al., 2007). However, $\mathrm{N}$ doses exceeding $20 \mathrm{~kg} \mathrm{ha}^{-1}$ were actually found to obstruct nodule formation in the plants (Embrapa, 2007). For NPP, experiment 1 alone registered a significant effect, and the treatment with the highest averages was the one which utilized the rooting product (Table 4). Thomas and Costa (2010) stated that the number of vegetables per plant 
is the productivity component having the highest adjustment potential. Therefore, when grain yields are to be boosted, managements that enhance the formation and maintenance of the vegetables on a plant must be implemented. The root enhancerss used in this experiment include nutrients in the formulation; and this may have minimized flower abortion, and thus increased pod formation.

None of the treatments affected the NGP number (Table 4). This is the component of productivity that exhibits low variations, a fact confirmed by other works using different inoculations, and nutrient usage in the seeds (Silva, 2010; Fipke, 2015; Perusso, 2013). The average values obtained concur with the one that is desired in genetic refinement, which are the vegetables having, on average, around two grains (Thomas and Costa, 2010). In this work, average values of 2.2 and 2.4 grains per legume were achieved for experiments 1 and 2, respectively.

Although MTG is a genetic trait, it can show variations in response to the nutritional status and health of the plant. In this study, the treatment using the standard inoculation and the one involving rooting presented the highest MTG for both the experiments; however, in the second experiment no difference was noted when compared with the uninoculated control (Table 4). Silva et al. (2011) also reported higher averages when mineral supplementation via the seeds was done, when compared to the control, justifying the rise to the part played by molybdenum as a nitrate reductase cofactor, thus increasing the nitrogen incorporation.

For GY, experiment 1 revealed significant interaction, wherein the treatments with the presence of water in the groove displayed higher productivity compared with those without water, for some treatments. When water was added to the sowing furrow, the highest yields were noted in the treatment using Bradyrhizobium, as well as in the treatment with the rooting, when both were used alone. All the other treatments showed no difference, statistically. In the second experiment, the treatment with rooting alone registered the highest GY, even better than the Bradyrhizobium treatment (Table 4).

The water added to the sowing furrow resulted in an increase of 401 and $73 \mathrm{~kg} \mathrm{ha}^{-1}$ for the first and second experiments, respectively. The other variables analyzed revealed no significant effect by this factor, for both sowing times (Table 5).

The soil moisture content during the evaluation period remained at $18 \%$ of the gravimetric moisture. No statistical difference was observed between the use or not of water in the sowing furrow. As the added water caused no difference to the soil moisture content, as well as due to the high soil moisture content during the first few days post sowing, we were unable to confirm the differences between the use of water during the infection and nodule formation processes.

\section{Materials and methods}

\section{Description of place and soil}

All the experimentation was performed at the Coxilha experimental area of the Department of Plant Sciences of the Federal University of Santa Maria - UFSM, in the municipality of Santa Maria, Rio Grande do Sul, at 29을 and 53 $73^{\prime} \mathrm{W}$ at $116 \mathrm{~m}$ altitude.
The soil in the region of the São Pedro Mapping Unit is of the Argissolo vermelho distrófico típico (Embrapa, 2013). The soil revealed the chemical and physical characteristics as listed: $\mathrm{pH}$ in water, 6.0; $\mathrm{MO}, 3.1 \%$; clay, 35\%; $\mathrm{P}$ Mehlich 1, $18.0 \mathrm{mg} \mathrm{dm}{ }^{3} ; \mathrm{K}, 0.286 \mathrm{cmol}_{\mathrm{c}} / \mathrm{dm}^{3} ; \mathrm{Ca}, 6.9 \mathrm{cmol}_{\mathrm{c}} / \mathrm{dm}^{3} ; \mathrm{Mg}$, $2.8 \mathrm{cmol}_{\mathrm{c}} / \mathrm{dm}^{3} ; \mathrm{S}, 10.8 \mathrm{mg} \mathrm{dm} \mathrm{dm}^{3} ; \mathrm{H}+\mathrm{Al}, 3.5 \mathrm{cmol}_{\mathrm{c}} / \mathrm{dm}^{3} ; \mathrm{CTC}$, $13.2 \mathrm{cmol}_{\mathrm{c}} / \mathrm{dm}^{3}$; V\%, 74.0. According to the Köppen classification, this area experienced the Cfa type of climatic conditions, typical of the humid subtropical region, with hot summers and no well-defined dry season (Alvares et al., 2014). The air temperature for the month of January, on average, was $24.7^{\circ} \mathrm{C}$ with $1712.4 \mathrm{~mm}$ mean annual rainfall, distributed evenly through the four seasons of the year (Heldwein et al., 2009).

\section{Experimental management}

The Nidera 6209 Roundup Ready cultivar from maturation group 6.2 was used. It had a type of determined growth, purple flowers, high branching potential, and a recommended plant population ranging from 280 to 350 thousand ha ${ }^{-1}$ plants (Nidera Seeds Ltda, Registry No. 29989). A sowing density of 35 seeds per $\mathrm{m}^{2}$ with $93 \%$ germination was used. Seed treatment was performed with the commercial product formulated with pyraclostrobin $25 \mathrm{~g} \mathrm{~L}^{-1}$ + thiophanate methyl $225 \mathrm{~g} \mathrm{~L}^{-1}+$ fipronil $250 \mathrm{~g} \mathrm{~L}^{-1}$ (Standak ${ }^{\circledR}$ Top) in the dosage of $2 \mathrm{~mL} \mathrm{~kg}^{-1}$ of seeds. Manual seed treatment was done utilizing $20 \mathrm{~L}$ capacity polyethylene bags, in which $3 \mathrm{~kg}$ of seeds were placed and product syrup added $6 \mathrm{~mL} \mathrm{~kg}^{-1}$ off seeds. Stirring was done for two minutes until the product was uniformly coated on the seeds.

The experimental unit was composed of five sowing rows, each row being $7.75 \mathrm{~m}$ long and with $0.45 \mathrm{~m}$ spacing between the rows, totaling to $17.43 \mathrm{~m}^{2}$ of total area per plot. Each of the three central rows from which the plants were collected were five meters long, totaling to a harvest area of $6.75 \mathrm{~m}^{2}$.

\section{Treatments}

Two experiments were installed at the time of the two sowing dates in the agricultural zone for the region, viz on 11/24/2015 for experiment 1 and 12/17/2015 for experiment 2 . The randomized block design experimental design was adopted, following a $7 \times 2$ factorial pattern, with four replicates. The inoculation treatments listed were done: non-inoculated (NI); not inoculated along with the nitrogen supply at the $200 \mathrm{~kg} \mathrm{ha}^{-1}(\mathrm{NI}+\mathrm{N})$; inoculation with the Bradyrhizobium [I (Brady)]; root enhancers (R); inoculation with Bradyrhizobium + root enhancers $(\mathrm{I}+\mathrm{R})$; co-inoculation with Bradyrhizobium + Azospirillum brasilense (I+Azo); co-inoculation with Bradyrhizobium + Azospirillum brasilense + root enhancers $(I+A z O+R)$. The second factor involved the use or abstinence of a water jet $\left(200 \mathrm{~L} \mathrm{ha}^{-1}\right)$ directed on the seeds in the sowing furrow (water in sowing furrow= with and without). This treatment was carried out with the aid of an inoculator in the furrow, whether or not pure water was applied to the sowing furrow.

The treatment with Bradyrhizobium involved the use of the liquid inoculant with $7 \times 10^{9}$ colony forming units (CFU mL ${ }^{-1}$ commercial product) of Bradyrhizobium japonicum strains CPAC 15 (SEMIA 5079) and Bradyrhizobium diazoefficiens strain CPAC 7 (SEMIA 5080), in the dose of $2 \mathrm{~mL} \mathrm{~kg}^{-1}$ of seeds. 
In the case of the Azospirillum treatments, a liquid inoculant containing Azospirillum brasilense strains Ab-V5 and Ab-V6 with $2 \times 10^{8} \mathrm{CFU} \mathrm{mL}^{-1}$ was used in the same dose of $2 \mathrm{~mL} \mathrm{~kg}^{-1}$ of seeds. The root enhancers used contained guarantees of: calcium (Ca) - $0.22 \mathrm{~g} \mathrm{~L}^{-1}$, sulfur (S) - $4.4 \mathrm{~g} \mathrm{~L}^{-1}$, molybdenum (Mo) - $5.5 \mathrm{~g} \mathrm{~L}^{-1}$, potassium $\left(\mathrm{K}_{2} \mathrm{O}\right)-2.2 \mathrm{~g} \mathrm{~L}^{-1}$ and zinc $(\mathrm{Zn})-8.8$ $\mathrm{g} \mathrm{L}^{-1}$, and added in the dose of $2 \mathrm{~mL} \mathrm{~kg}^{-1}$ of seeds. For the inoculation, each treatment involved the use of $3 \mathrm{~kg}$ of seeds placed in a seed volume was shaken polyethylene bag $(20 \mathrm{~L})$, to which the inoculant was added. The syrup volume $(6 \mathrm{~mL}$ $\mathrm{kg}^{-1}$ ) was homogenized onto the seeds. Post inoculation the seeds were shade-dried for 30 minutes.

Basic fertilization was performed in accordance with the Commission of Chemistry and Soil Fertility (CQFS-RS/SC, 2016). Employing the seeder furrow system, fertilization with $\mathrm{P}_{2} \mathrm{O}_{5}$ and $\mathrm{K}_{2} \mathrm{O}$ was done, using $300 \mathrm{~kg} \mathrm{ha}^{-1}$ of NPK formulation 00-23-30; this formula was obtained through manually mixing the triple superphosphate with potassium chloride. For the control with $\mathrm{N}$, the $200 \mathrm{~kg} \mathrm{ha}^{-1}$ were separated into four distinct applications of $50 \mathrm{~kg} \mathrm{ha}^{-1}$, in the stages V2, V4, V6 and R1. The other cultural treatments were performed, in keeping with the technical indications for the culture in the Rio Grande do Sul (Technical Indications for the Culture of Soy in Rio Grande do Sul and Santa Catarina, harvests 2014/2015 and 2015/2016 (Embrapa, 2014).

\section{Analyzed variables}

For experiments 1 and 2 the soil temperature was assessed up to 14 and 7 days, respectively, post sowing. Three split-type thermometers ( $12 \mathrm{~cm}$ of stem) were placed in the sowing furrow, and the readings were taken twice a day (at 9:00 a.m. and 3:00 p.m.) at the three depths of 1,5 , and 10 $\mathrm{cm}$. The soil moisture was estimated until the first rainfall post sowing, for a total of three days for experiment 1 and on no days at all for experiment 2 . A cutting shovel was used to collect the soil in the sowing line $(20 \times 10 \times 5 \mathrm{~cm})$. The initial plant population (IP) was recorded in the V2 (first fully developed trifoliate leaf) (Fehr and Caviness, 1977), with the counting being done at $2 \mathrm{~m}$ in the center of the three central rows of each plot. The phenological stage was characterized by the time of full flowering and the presence of an open flower in one of the last two nodes of the stem bearing a fully developed leaf. At this stage, the plants were collected and the nodules counted. From each plot, four plants were collected, and the number of nodules per plant (NNP, no plant $^{-1}$ ) from among these, was recorded. The nodules were then washed and dried in a forced circulation air oven at 60 ㄷ $\mathrm{C}$ until constant mass was reached. The dry mass of the nodules per plant (MNP, g plant ${ }^{-1}$ ) was determined using a balance with the precision of three decimal places. The aerial plant parts collected to ascertain the nodule count were packed in paper bags and dried in a forced circulation air oven at 60 으 until constant mass was achieved to assess the dry mass of plants (DMP, g plant ${ }^{-1}$ ).

At the R8 stage $95 \%$ of the pods showed mature staining. The plant count was repeated just as it was done for V2, which was responsible for the final plant population (FPP). In this stage, five plants per plot were sampled to ascertain the constituents of plant productivity and growth. Counting was done for the number of pods per plant (NPP, no plant ${ }^{-1}$ ), and the number of grains per pod (NGP, $n$ o pod-1), separating the vegetables having one, two, three and four grains. The insertion heights of the first pod (IFP, $\mathrm{cm}^{-1}$ ) and the plant heights $\left(\mathrm{PH}, \mathrm{cm}^{-1}\right)$ were also determined using these plants. Harvesting was done with a mowing machine, and the harvested plants were cleaned. Later, these plants were weighed, and the moisture content corrected to $13 \%$ to get the grain yield ( $\mathrm{GY}, \mathrm{kg} \mathrm{ha}^{-1}$ ) and mass of a thousand grains (MTG, g).

\section{Statistical analysis}

The results were submitted to the assumptions of the mathematical model (Steel et al., 1997), and later to the analysis of variance (ANOVA) by the $F$ test. For the means of those variables showing statistical difference the Scott-Knott test of the comparison of averages was done, with $5 \%$ probability, using the statistical software, $\operatorname{SISVAR}^{\circledR}$ (Ferreira, 2011).

\section{Conclusions}

Water supplied to the sowing furrow had no effect on soybean nodulation and yield components.

Co-inoculation promoted nodulation in soybean plants, particularly in dry mass of the nodules and number of nodules per plant.

\section{Acknowledgments}

This study was financed in part by the Coordenação de Aperfeiçoamento de Pessoal de Nível Superior - Brasil (CAPES) - Finance Code 001.

\section{References}

Aguila LSH, Aguila JA, Theisen G (2011) Perdas na colheita da cultura da soja. Pelotas: Embrapa Clima Temperado, 12p. (Embrapa Clima Temperado. Comunicado Técnico 271).

Alvares, Clayton Alcarde, Alvares, CA, Stape JL, Sentelhas PC, de Moraes G, Leonardo J, Sparovek G (2013) Köppen's climate classification map for Brazil. Meteorologische Zeitschrift. 22 (6): 711-728.

Bárbaro IM, Machado PC, Bárbaro Junior LS, Ticelli $M$, Miguel FB, Silva JD (2009) Produtividade da soja em resposta à inoculação padrão e co-inoculação. Colloq Agrariae. 5: 1-7.

Benintende S, Uhrich W, Herrera M, Gangge F, Estrelas M, Benintende $M$ (2010) Comparación entre coinoculación com Bradyrhizobium japonicum y Azospirillum brasilense e inoculación simple com Bradyrhizobium japonicum en la nodulación, crecimiento y acumulación de $\mathrm{N}$ en el cultivo de soja. Agriscientia. 23 (2): 71-77.

Brandelero EM, Pereira Peixoto C, Ralisch R. (2009) Nodulação de cultivares de soja e seus efeitos no rendimento de grãos. Semina: Ciênc Agrár. 30 (3): 581-588.

Campos BC, Hungria M, Tedesco V (2001) Eficiência da fixação biológica do $\mathrm{N}_{2}$ por estirpes de Bradyrhizobium na soja em plantio direto. Rev Bras Cienc Solo. 25: 583-592.

Castro PRC, Vieira EL (2001) Aplicações de reguladores vegetais na agricultura tropical. Guaíba: Agropecuária.

Conab: Companhia Nacional De Abastecimento (2017) Acompanhamento da Safra Brasileira de Grãos. Monitoramento agricola- Safra 2016/2017. 4: 1-174. 
CQFS-RS/SC - Comissão de Química e Fertilidade Do Solo (2016) Manual de adubação e calagem para os Estados do Rio Grande do Sul e Santa Catarina. Porto Alegre, SBCS, 376p.

Domingos CS, Da Silva Lima LH, Braccini AL (2015) Nutrição mineral e ferramentas para o manejo da adubação na cultura da soja. Sci Agrar Parana. 14: 132-140.

Embrapa (2014). Empresa Brasileira De Pesquisa Agropecuária. Indicações Técnicas para a Cultura da Soja no Rio Grande do Sul e em Santa Catarina, safras 2014/2015 e 2015/2016. Pelotas: Embrapa Clima Temperado, 124 p. (Embrapa Clima Temperado. Documentos, 382).

Embrapa - Empresa Brasileira De Pesquisa Agropecuária (2013) Sistema brasileiro de classificação de solos. 3. ed. Brasília, 353p.

Embrapa - Empresa Brasileira De Pesquisa Agropecuária (2007) Tecnologias de produção de soja - região central do Brasil. Londrina: Embrapa Soja.

Fehr WR, Caviness CE (1977) Stages of soybean development. Ames: lowa State University, 12 p. (Special Report, 80).

Ferreira DF (2011) Sisvar: a computer statistical analysis system. Ciênc Agrotec. 35:1039-1042.

Fipke GM (2015) Co-inoculação e pré-inoculação de sementes em soja. 67p. Dissertação (Mestrado em Agronomia) - Universidade Federal de Santa Maria, Santa Maria.

Floss EL (2011) Fisiologia das plantas cultivadas. Passo Fundo: UPF, 536p.

Heldwein AB, Buriol AG, Streck NA (2009) O clima de Santa Maria. Ciênc Amb, 38: 43-58.

Henning AA (2005) Patologia e tratamento de sementes: noções gerais. Londrina: Embrapa Soja. 2005. (Documentos, 264)

Hungria M, Nogueira MA, Araujo RS (2015) Alternative methods of soybean inoculation to overcome adverse conditions at sowing. Afr J Agric Res. 10: 2329-2338.

Hungria M, Nogueira MA, Araujo RS (2013) Co-inoculation of soybeans and common beans with rhizobia and azospirilla: strategies to improve sustainability. Biol Fertil Soils. 49: 791-801.

Hungria M, Campo RJ, Mendes ICA (2007) Importância do Processo de Fixação Biológica do Nitrogênio para a Cultura da Soja: Componente Essencial para a Competitividade do Produto Brasileiro. Londrina: Embrapa Soja.(Embrapa Soja. Documentos, 283)

Hungria M, Franchini JC, Campo RJ, Graham PH. (2005) The importance of nitrogen fixation to soybean cropping in South America. In: Werner, D. and Newton, W.E. (Ed.). Nitrogen fixation in agriculture: forestry ecology and environment. Dordrecht, Kluwer Academic Publishers, 25-42.

Hungria M, Vargas MAT (2000) Environmental factors affecting $\mathrm{N}_{2}$ fixation in grain legumes in the tropics, with an emphasis on Brazil. Field Crops Research. 65: 151-164.

Hungria M, Stacey G (1997) Molecular signals exchanged between host plants and rhizobia: basic aspects and potential application in agriculture. Soil Biol Biochem. 29: 519-830.

Kloepper JW, Lifshitz R, Zablotowicz RM (1989) Free-living bacterial inocula for enhancing crop productivity. Trends in Biotechnology. 7: 39-43.
Marcos Filho J (1986) Germinação de sementes. In: Semana de atualização em produção de sementes. Piracicaba, 1986. Campinas: Fundação Cargill. 11-39, 1986.

Ormeno-Orrillo E, Hungria M, Martinez-Romero E (2013) Dinitrogen-fixing prokaryotes. In: Rosenberg E, DeLong EF, Lory $S$ et al. (eds). The Prokaryotes. Prokaryotic Physiology and Biochemistry. Berlin-Heidelberg: Springer. 427-51.

Paiola Albrecht L, Lucca E Braccini AD, Rizzatti Ávila M, Suzuki LS, Scapim CA, Cezar Barbosa M (2008) Teores de óleo, proteínas e produtividade de soja em função da antecipação da semeadura na região oeste do Paraná. Bragantia. 67: 865-873.

Peell MC, Finlayson BL, Mcmahon TA (2007) Updated world map of the Köppen-Geiger climate classification. Hydrol Earth Syst Sci. 11: 1633-1644.

Perini LJ, da Silva Fonseca Júnior N, Destro D, Cavenaghi Prete CE (2012) Componentes da produção em cultivares de soja com crescimento determinado e indeterminado. Semina: Ciênc Agrár. 33: 2531-2544.

Perusso LP (2013) Componentes de rendimento da cultura da soja em função da aplicação de nitrogênio no florescimento. 2013. 40p. Dissertação (Mestrado em Agronomia) - Universidade Federal de Santa Maria, Santa Maria.

Prado RM (2008) Nutrição de plantas. São Paulo: Editora da UNESP, $407 \mathrm{p}$.

Sediyama T (2009) Tecnologias de produção e usos da soja. Londrina: Mecenas, 314p.

Sfredo GJ, Oliveira MCN (2010) Soja: molibdênio e cobalto. Londrina: Embrapa Soja.

Sfredo GJ, Borkert CM (2004) Deficiências e toxicidades de nutrientes em plantas de soja. Londrina: Embrapa Soja. (Documentos, n.231).

Silva AF, Schoninger EL, Monteiro S, Caione G, de Carvalho, MAC., Dalchiavon, FC, Noetzold R (2011). Inoculação com bradyrhizobium e formas de aplicação de cobalto e molibdênio na cultura da soja. Agrarian. 4: 98-104.

Steel RGD, Torrei JH, Dickey D, (1997) A. Principles and procedures of statistics: a biometrical approach. 3. ed. New York: McGraw Hill Book, 666p.

Thomas AL, Costa JA (2010) Desenvolvimento da planta de soja e potencial de rendimento de grãos. In: Thomas AL, Costa JA (Org.) Soja: manejo para alta produtividade de grãos. Porto Alegre: Evangraf.

Tien TM, Gaskins MH, Hubbell DH (1979) Plant growth substances produced by Azospirillum brasilense and their effect on the growth of pearl millet (Pennisetum americanum L.). Appl Environ Microbiol. 37: 1016-1024. 